\title{
Respect for individual autonomy and a collective benefit: Arguments in favor of compulsory SARS-CoV-2 vaccination among health care professionals
}

Ezequiel Monteverde, M.D. ${ }^{a}$ a. Intensive Care Unit, Hospital de Niños Ricardo Gutiérrez; Fundación

Trauma, director of registration system.

E-mail address:

Ezequiel

Monteverde, M.D.: ezequielmonteverde@ gmail.com

Funding:

None.

Conflict of interest:

None.

Received: 1-21-2021

Accepted: 3-18-2021

\begin{abstract}
With the development of SARS-CoV-2 vaccines, a new aspect to be taken into consideration in the midst of the pandemic is vaccine refusal. Since vaccination is voluntary, it is necessary to deal with the fact that some health care team members refuse to receive it. Here I put forward different bioethical arguments: Kantian deontology and the principles of universalizability, humanity, and autonomy; Mill's utilitarianism, with selfprotection as the sole end for which humankind is authorized to interfere with its members' freedom of action; Beauchamp and Childress' principlism and the concepts of beneficence and autonomy; Varo Baena's principle of opportunity; and the principle of solidarity resulting from the ethics of human rights. The contributions of contemporary philosophers like Roberto Espósito, Jean-Luc Nancy, and Alberto Giubiliniare also included. Two counterarguments are presented: nonmaleficence and counter-production. Lastly, I suggest that, since common good (in this case, public health) is the intimate and final determining factor of individual freedom and is the same for all, it is above any individual benefit.
\end{abstract}

Key words: bioethics, COVID-19, utilitarianism, deontology, human rights.

http: / / dx.doi.org/ 10.5546/ aap.2021.eng.e298

\section{INTRODUCTION}

An aspect related to the novel coronavirus disease (COVID-19) pandemic and one of the solutions available to the world - mass vaccination- filled the pages of the mass media since the early vaccines were approved by regulatory agencies. Counter-intuitively, after a year of restrictions and human resource loss among the health care team, this intervention, considered a potential solution, is being resisted in some parts of the world. ${ }^{1-4}$ To date, vaccination is voluntary worldwide. Therefore, we are faced with how to deal with vaccine refusal among those who are part of, for example, groups of people (health care professionals or not) who work in health-related settings (hospitals, laboratories, diagnostic imaging centers) or nursing facilities, such as elderly residences. Should different citizens have different schedules based on their roles?

To cite: Monteverde E. Respect for individual autonomy and a collective benefit: Arguments in favor of compulsory SARS-CoV-2 vaccination among health care professionals. Arch Argent Pediatr 2021;119(4):e298-e302.

\section{Classical contributions from bioethics}

Some answers may be assessed from the point of view of classical doctrines of bioethics, deontology (Kant), and teleology (Mill) or the theory of principles (Beauchamp and Childress). Kant's categorical imperative is presented in three formulations that make up the core of his ethical philosophy: universalizability (acting based on maxims that can be applied to all people), humanity (people as an end in themselves and not as a means to something else), and autonomy (people's capacity to decide for themselves). ${ }^{5}$ The possibility of 
refusing to receive a vaccine based on the principle of universalizability would only be tolerable in a world where everyone refused vaccination. This is contrary to the current majority opinion and to the prevention standard that has been in place for decades in most countries. If it was proposed to have some people vaccinated while others were not (the latter known as "those who receive the benefits of a collective good without contributing to its production" or free riders), ${ }^{6}$ vaccinated people would be used as a means to achieve herd immunity and protect those who are not, which would also be unacceptable. Autonomy is the most controversial aspect because, when living in a community, each individual should contribute something (munus, the contribution each member of the community should make to continue being a member) for the common good, and such decision may be against individual beliefs. ${ }^{7}$ A libertarian person may say that the purpose of the categorical imperative may be the respect for an individual decision, thus complying with the first (each person makes their own decision about the immunization schedule), second (respect for each person's will, on the grounds that a massive rejection is tolerable for them), and third formulations (because such decisions are made in full force of each individual's autonomy). Based on the preceding, the question that arises is whether health is a common goal, whether health is a fully individual possibility in an unhealthy community setting, and what happens with people who, due to their age or health conditions (active disease, comorbidities), cannot receive the vaccine but would benefit from herd immunity resulting from those who are vaccinated. According to Aristotle, human beings are by nature political animals, "human beings are by nature social animals and... the city-state is prior in nature to the household and to each of us individually, for the whole must necessarily be prior to the part. ${ }^{8}$ Based on that statement, are not we all obliged to provide such munus to support the minimum structure of our community?

In addition, the harm principle by John S. Mill, who stated that "the only reason to restrict an individual's action is to prevent harm to others," is also useful to consider the problem from a different perspective because this principle is one of the pillars of classical liberalism. ${ }^{9}$ The general consideration is that the main purpose of liberalism is the protection and promotion of individual autonomy, and Mill is often quoted as one of its supporters. Although it is true that Mill believed that individual autonomy was not negotiable, he promoted social progress fueled by individuals and understood that the latter were the actual motor of change. ${ }^{10}$ Thus, the harm principle was useful to balance the social progress promoted by individuals and social order. In his book On Liberty, Mill states: "The object of this essay is to assert one very simple principle, as entitled to govern absolutely the dealings of society with the individual in the way of compulsion and control, whether the means used be physical force in the form of legal penalties, or the moral coercion of public opinion. That principle is that the sole end for which mankind are warranted, individually or collectively, in interfering with the liberty of action of any of their number is self-protection. That the only purpose for which power can be rightfully exercised over any other member of a civilized community, against his will, is to prevent harm to others. (...) If any one does an act hurtful to others, there is a prima facie case for punishing him, by law, or, where legal penalties are not safely applicable, by general disapprobation". ${ }^{11}$

In relation to bioethics in the principles by Beauchamp and Childress, it is easy to find beneficence if we agreed that there is no other public health intervention that has benefited humankind as much as improved access to water and food and vaccines..$^{12}$ In relation to the principle of nonmaleficence, it may be affected when considering those who may be harmed; however, how many therapeutic, preventive or diagnostic interventions are free from risks? None. For this reason, raising an argument against vaccines is raising an argument against medicine as a whole, and this is how the problem should be addressed. Certainly, justice is currently the most violated principle because, based on present information, it is possible to claim that access to vaccination will not be equal. ${ }^{13}$ In relation to the principle of autonomy (the principle of respect for autonomy, according to Childress), the ethics of the principles itself proposes that it may be overcome or violated when the following conditions are met: proportionality (stronger competing principles), effectiveness (infringing the principle of autonomy protects the competing principles), last resort (the need to protect the competing principles), and the least infringement (being the least intrusive or restrictive aspect in specific circumstances). ${ }^{14,15}$ Varo Baena ${ }^{16}$ proposed to introduce a fifth principle to the four principles 
mentioned before: the principle of opportunity, which is especially relevant in our current situation and for the question raised in this article. This concept refers to the question of whether there is a moral responsibility of vaccination in a specific moment and under certain collective and social conditions. If we consider that the same intervention in two different historical moments would have different consequences, it is clear that such consideration includes not only operational but also ethical aspects. The accelerated authorization of vaccines is proof of this.

\section{What do contemporary philosophers think of this?}

Jean-Luc Nancy picks up Karl Marx for the analysis of the current tension between individual autonomy and collective beneficence. In Marxist terms, there is no autonomy -or there is only for a few- because individuals are alienated. Therefore, the individual versus community approach is untrue because the alleged benefits of an individual perspective are not such, they are not available. Such altered perception, where individuals consider themselves free, autonomous, and capable of choosing for themselves, is the result of the alienating system itself; for this reason, paradoxically, those who claim individual liberty are the staunch defenders of a system that dispossesses them of their being. ${ }^{17}$ For example, how can a person with no access to safe water wash their hands often ${ }^{18}$ According to Nancy: "What is typical of individuals is that they are incomparable, immense, and incomprehensible, even by themselves. It is not a matter of possessions, it is about being unique, exclusive, and whose exclusive uniqueness, by definition, is only realized among and with all; against or in spite all, but always involved in the relationship and exchange (communication)" ${ }^{19}$ The pandemic threatened our autonomy, revealed our interconnection, and focused on relational aspects that provide a fake concept of autonomy. The absence of autonomy evidenced that we need to lean on each other to achieve our goals, but how do we do it? Is it possible to lean on each other based on equality? Can resources be distributed in such a manner that we would recognize each other as equals? Certainly not, as shown by the distribution of the first vaccine doses. ${ }^{13}$ Roberto Espósito, an Italian philosopher whose work may be described as biopolitical, analyzed the association between two concepts: "community" (politics) and "immunity" (medicalepidemiological). Both share the munus root: community is thus a human group brought together by a common law and obligation, but also by a contribution (each individual offers their share to the common good, which is then used as guiding principle). On the other side, immunity was a privilege conferred to certain community members who did not have to provide the munus, and is still seen nowadays, for example, in terms of parliamentary or diplomatic immunity. ${ }^{20}$ Thus, the community arranges itself around such obligations and contributions.

Also based on deontology, Alberto Giubilini challenges the argument of harm to others and proposes an analogy between vaccine refusal and tax evasion, and quotes a fragment from On Liberty: “... every one who receives the protection of society owes a return for the benefit (...) renders it indispensable that each should be bound to observe a certain line of conduct towards the rest. This conduct consists, first, in not injuring the interests of one another (...) in each person's bearing his share (to be fixed on some equitable principle) of the labors and sacrifices incurred for defending society or its members from injury and molestation." ${ }^{11}$ This means that, since the individual contributions of a person are unlikely to have an impact on a group level, beyond harming or not being good for others, the inclusion of labor and sacrifice is based on the concept of equity, i.e., what we have to do as parts of a whole. ${ }^{21}$ To this end, there are moral justifications (a small individual effort to achieve an important collective good) and also legal ones (to the extent that the goods at stake are relevant for society, the implementation of legal strategies to attain them is justified). As in the case of tax payment, the State is obliged to warrant equal vaccination: the individual duty of making contributions is positively reinforced as more and more individuals take part in the compulsory vaccination campaign.

\section{Two arguments to be considered}

Although compulsory vaccination may be questioned under the nonmaleficence principle because current vaccines have been approved before completing phase III trials and with an insufficient follow-up time to document adverse events in the median and long term, this argument is based on two false allegations. On the one side, it assumes that the only risk for health is that of developing adverse events due to 
the vaccine but overlooks the risk from becoming infected. On the other side, it is worth asking what the cost of infection is to third parties because an individual decided not to get vaccinated and what would happen if such person was in contact (at work, socially, etc.) with people who have a greater risk for a severe clinical presentation. In some countries, like the United States, establishing mandatory SARS-CoV-2 vaccination with vaccines approved by virtue of an emergency use authorization is problematic from a legal and an ethical perspective because this type of authorization has looser safety and effectiveness requirements than a full authorization. ${ }^{22}$ However, section 7 of Argentinian Law no. 27491 supports such mandatory nature in case of "an epidemiological emergency". ${ }^{23}$

Another argument against compulsory vaccination is that it may result in a counterproductive measure. Under the assumption that, if the vaccine was so good, everyone would want to receive it and there would be no need to make it mandatory, it is believed that the population will be convinced that any compulsory measure will always be rejected. Moreover, some people claim that individuals will most likely have no confidence in compulsory vaccines approved by virtue of an emergency use authorization and consider them part of a covert investigation. ${ }^{22}$ However, the experiences of Italy and France in relation to the MMR vaccine campaigns after observing a significant increase in measles cases refute such argument, ${ }^{24,25}$ without overlooking the fact that, given the ethical and cultural heterogeneity among countries, there is not a single solution for all. ${ }^{26}$

\section{CONCLUSION}

In the traditional approach of individual liberty versus a collective benefit, brought to the current pandemic context, there is always a loss of liberty (when defined as the ability to act according to one's own decision) ${ }^{19}$ no matter the intervention proposed. According to this definition, liberty and respect for autonomy ${ }^{14}$ are equivalent categories. In my opinion, the defense of full individual liberty, without limitations, is too naive to even be considered. No modern philosophy or theology has assigned individuals with liberty as a plain and simple self-determination power. ${ }^{19}$ The intimate and ultimate determining factor of individual liberty is that it is equal for all: all human beings are equally and identically free and, as long as we continue living in urban areas (polis), we will find ourselves converging between the Kantian universalizability (wearing masks is a clear example) and the utilitarian perspective. This is because, when acting in this manner, benefits would be maximized, such as a lower number of infected people, fewer severely ill people, and fewer deaths attributed to COVID-19.

In relation to health care team members, it is worth considering whether it would be reasonable to enforce sanctions on health care team members who refuse to get vaccinated or who disseminate fake news about the vaccines. ${ }^{27}$ In relation to this, it is necessary to consider two approaches. On the one side, and in accordance with Espósito, I believe that, although reserving immunity to certain members of the community has always been influenced by the power dynamics of each place and time, this time it should be given to those with contraindications for vaccination. On the other side, since these people require more health care interventions, it is reasonable to wonder who else, if not health care team members, should provide such "privilege" through a safe contact with vaccinated professionals. Secondly, this principle is also consistent with that of solidarity in relation to the bioethics of human rights based on the ramifications of the Universal Declaration on Bioethics and Human Rights by the United Nations Educational, Scientific and Cultural Organization: ${ }^{28}$ solidarity, together with cooperation, are key to achieve the highest level of health, with special regard for vulnerable groups.

As mentioned, the bioethics of vaccination is a synthesis of Kantian deontology and utilitarian ethics. Moreover, such recognition is also found in sections 2 (paragraph C) and 7 of the Argentine law, which assigns public health a value that is above that of individual interests, especially in an epidemiological emergency. ${ }^{23}$ Lastly, in this context, it is not possible to implement the last resort policy ${ }^{29}$ because the level of uncertainty is too high and subscribing to this line would lead to breaching the argument of opportunity. In a time when reality is permanently modified (a koinos kosmos or shared universe impossible to achieve), in the context of widely disseminated fake news and scientific articles that are refuted once published by the most prestigious journals, I believe it is our responsibility, as members of the health care team, to set the example.

\section{REFERENCES}

1. Coronavirus en EE.UU.: con casi 300.000 casos nuevos en un día, crece el rechazo de médicos y enfermeros a la vacuna. 
Clarín. Buenos Aires. 3 de enero de 2021. [Accessed on: January $\left.14^{\text {th }}, 2021\right]$. Availableat:https: / / www.clarin.com/ mundo/vacuna-crece-rebelion-personal-salud-unidospese-avance-coronavirus_0_ZCtRYS-fb.html.

2. Facebook, Twitter, options $S$ more sharing, LinkedIn, et al. Some healthcare workers refuse to take COVID-19 vaccine, even with priority access. Los Angeles Times 2020. California. Dec 31, 2020. [Accessed on: January $14^{\text {th }}$, 2021]. Available at:https: / www.latimes.com/ california / story / 2020-12-31 / healthcare-workers-refuse-covid-19vaccine-access.

3. Zas Marcos M. Sanidad registrará las razones de quienes se nieguen a ponerse la vacuna contra la COVID-19. ElDiario.es. Madrid. 21 de diciembre de 2020. [Accessed on: January $14^{\text {th }}$, 2021]. Available at: https: / / www.eldiario. es/sociedad/sanidad-registrara-razones-rechazo-vacunacovid-19_1_6521846.html.

4. Pinault N. Francia se enfrenta al rechazo de la población a la vacuna contra elCOVID-19. Voice of America.30 denoviembre de2020. [Accessed on:January $14^{\text {th }}, 2021$ ]. Availableat:https:/ / www.voanoticias.com/ coronavirus / francia-resistenciapublica-vacuna-contra-covid19.

Kant I. La autonomía de la voluntad como principio supremo de la moralidad. In: Kant I. Fundamentación para una metafísica de las costumbres. 5. ${ }^{a}$ reimp. Madrid: Alianza; 2019:157-8.

5. Hardin R, Cullity G. The Free Rider Problem. In: Zalta EN (ed). The Stanford Encyclopedia of Philosophy. Winter 2020 ed. Stanford: Metaphysics Research Lab, Stanford University; 2020.

6. Rivera Castro F. El imperativo categórico en la Fundamentación de la Metafísica de las Costumbres. Rev Digit Univ. 2004; 5(11):83.

7. Aristóteles.LibroI.In:Aristóteles.Política. Madrid:Gredos; 1988.Pages.50-1.

8. Taylor JS. The Harm Principle. Libertarianism.org. Washington DC. Jun 21, 2011. [Accessed on: January $17^{\text {th }}$, 2021]. Available at: https://www.libertarianism.org/ media/around-web/harm-principle.

9. Yaylali M. El principio del daño: El equilibrio del progreso social en la filosofía política de John Stuart Mill. Foro Interno. 2019; 19:77-92.

10. Mill JS. On Liberty. In Mill JS. On liberty, utilitarianism, and other essays. $2^{\text {nd }}$ ed. New York: Oxford University Press; 2015; 14:65-6.

11. Greenwood B. The contribution of vaccination to global health: past, present and future. Philos Trans $R$ Soc Lond B Biol Sci. 2014; 369(1645):20130433.

12. VOA News. $95 \%$ of World's Vaccines Being Administered in 10 Countries, WHO Official Says. Voice of America January 14, 2021. [Accessed on: January 17 1 th 2021]. Available at: https:/ / www.voanews.com/ covid-19-pandemic/95worlds-vaccines-being-administered-10-countries-whoofficial-says.
13. Childress JF. El lugar de la Autonomía en la Bioética. In: Luna F, Salles ALF. Bioética: investigación, muerte, procreación y otros temas de ética aplicada. 2. ${ }^{a}$ ed. Buenos Aires: Sudamericana; 2000.Pages.133-44.

14. Childress JF, Faden RR, Gaare RD, Gostin LO, et al. Public health ethics: mapping the terrain. J Law Med Ethics. 2002; 30(2):170-8.

15. Varo Baena A. Vaccine bioethics and public health. Vacunas (English Edition). 2020; 21(1):57-63.

16. Marx K. El trabajo enajenado. In: Marx K. Manuscritos de economía y filosofía. Madrid: Alianza; 2003.Pages.104-20.

17. Vera F, Adler V, Uribe MC (eds). ¿Qué podemos hacer para responder al COVID-19 en la ciudad informal? Banco Interamericano de Desarrollo; 2020. [Accessed on: January 19th, 2021$]$. Available at: https://publications.iadb.org/ es / que-podemos-hacer-para-responder-al-covid-19-enla-ciudad-informal.

19. Nancy JL. Un virus demasiado humano. Adrogué: La Cebra; 2020.

20. Espósito R. Immunitas. Protección y Negación de la Vida. Buenos Aires: Amorrortu; 2005.

21. Giubilini A. An Argument for Compulsory Vaccination: The Taxation Analogy. J Appl Philos. 2020; 37(3):446-66.

22. Gostin LO, Salmon DA, Larson HJ. Mandating COVID-19 Vaccines. JAMA. 2021; 325(6):532-3.

23. Ley 27491. Control de enfermedades prevenibles por vacunación. Buenos Aires, Argentina. 4 de enero de 2019. [Accessed on: January 19 $\left.{ }^{\text {th }}, 2021\right]$. Available at: https: / / www.argentina.gob.ar/normativa/ nacional/ ley-27491318455.

24. D'Ancona F, D'Amario C, Maraglino F, Rezza G, et al. Introduction of new and reinforcement of existing compulsory vaccinations in Italy: first evaluation of the impact on vaccination coverage in 2017. Euro Surveill. 2018; 23(22): 1800238

25. Lévy-Bruhl D, Fonteneau L, Vaux S, Barret A-S, et al. Assessment of the impact of the extension of vaccination mandates on vaccine coverage after 1 year, France, 2019. Euro Surveill. 2019; 24(26):1900301.

26. Drew L. The case for mandatory vaccination. Nature. 2019; 575:S58-60.

27. Güel O, García A. Inhabilitada una pediatra por propagar que las vacunas causan el autismo. EL PAÍ́S. Barcelona/ Madrid.21 dejuniode2019. [Accessed on:January $18^{\text {th }}, 2021$ ]. Available at: https: / / elpais.com/sociedad/2019/06/20/ actualidad/1561034181_540468.html.

28. UNESCO. Declaración universal sobre Bioética y Derechos Humanos. 2005. [Accessed on: January 19 ${ }^{\text {th }}, 2021$ ]. Available at: http:/ / portal.unesco.org/es/ev.php-URL_ $\mathrm{ID}=31058 \& U R L \_D O=D O \_T O P I C \& U R L \_S E C T I O N=201$. html.

29. Moorthy G. Compulsory COVID-19 Vaccination? Only as a Policy of Last Resort. VIB. 2020;6. [Accessed on: January 19 ${ }^{\text {th }}$ 2021]. Available at: https: / / journals.library.columbia. edu/index.php/bioethics/article/view/7301. 